\title{
PENGARUH BEBERAPA JENIS FUNGISIDA SEBAGAI PERLAKUAN BENIH JAGUNG TERHADAP KELIMPAHAN DAN KERAGAMAN ARTROPODA TANAH
}

\author{
Diny Fitryana, I Gede Swibawa, Muhammad Nurdin \& F.X. Susilo \\ Jurusan Agroteknologi, Fakultas Pertanian, Universitas Lampung \\ Jl. Prof. Soemantri Brojonegoro, No. 1 Bandar Lampung 35145 \\ Email: igede.swibawa@fp.unila.ac.id
}

\begin{abstract}
ABSTRAK
Penelitian ini bertujuan untuk mempelajari pengaruh beberapa jenis fungisida sebagai perlakuan benih jagung terhadap kelimpahan dan keragaman artropoda tanah. Penelitian ini dilaksanakan di lahan petani Natar Lampung Selatan, dari bulan Januari sampai dengan Juni 2016. Penelitian ini menggunakan Rancangan Acak Kelompok (RAK) dengan 10 perlakuan yang terdiri dari 9 perlakuan fungisida dan 1 kontrol serta dibuat dalam 3 ulangan. Satuan percobaan adalah benih jagung yang ditanam pada polibag berkapasitas $5 \mathrm{~kg}$. Variabel yang diamati yaitu kelimpahan dan keragaman artropoda tanah. Sampel tanah diambil menggunakan ring sampel dan artropoda diekstraksi menggunakan Berlese funnel dan artropoda yang ditemukan diidentifikasi sampai tingkat famili. Data yang diperoleh dianalisis kovarians (ANKOVA) pada taraf nyata 5\%. Hasil penelitian menunjukkan bahwa terdapat 9 famili dan 4 subordo yang ditemukan pada pertanaman jagung yang terdiri dari 3 kelompok makan yaitu predator, saprofag dan mikrofitik. Perlakuan benih menggunakan fungisida tidak berpengaruh terhadap kelimpahan seluruh artropoda, kelimpahan artropoda predator, kelimpahan artropoda saprofag dan kelimpahan artropoda mikrofitik serta keragaman artropoda.
\end{abstract}

Kata kunci: Artropoda tanah, fungisida, perlakuan benih, tanaman jagung

\section{PENDAHULUAN}

Jagung (Zea mays L.) merupakan salah satu tanaman pangan penting dunia selain gandum dan padi. Dalam budidaya jagung ditemukan berbagai kendala, salah satunya adalah gangguan penyakit yang menyebabkan produksi tanaman tidak optimum. Salah satu penyakit penting tanaman jagung adalah bulai yang disebabkan oleh jamur Peronosclerospora maydis. Serangan jamur penyebab bulai dapat menurunkan produksi hingga 90\% dan bahkan dapat menyebabkan kegagalan panen (Semangun, 1993).

Perlakuan benih menggunakan fungisida dapat diterapkan untuk pencegahan munculnya penyakit bulai. Fungisida merupakan pestisida yang bahan racunnya dapat menyebabkan dampak negatif bagi lingkungan jika penggunaannya tidak tepat. Aplikasi fungisida pada benih jagung diduga akan berdampak buruk bagi lingkungan di dalam tanah seperti biota tanah.

Penggunaan fungisida bertujuan untuk mengendalikan atau menekan pertumbuhan jamur. Jika jamur dikendalikan dengan fungisida melalui perlakuan benih, maka kelimpahan jamur di dalam tanah akan berkurang. Kondisi semacam ini dapat menyebabkan artropoda pemakan miselia jamur mengalami keterbatasan sumber nutrisi sehingga aktivitas dan kelimpahannya akan tertekan. Menurut Scheu dan Folger (2004, dalam Andriani, dkk., 2012), beberapa kelompok taksa mesofauna tanah menyukai miselia jamur (kapang) sebagai salah satu sumber nutrisinya. Apabila pertumbuhan jamur tertekan oleh pestisida, maka kelompok artropoda pemakan jamur juga akan terganggu.

Penggunaan fungisida sebagai perlakukan benih pada tanaman jagung diduga dapat menyebabkan penurunan kelimpahan dan keragaman artropoda tanah, namun informasi mengenai hal ini perlu dipelajari lebih lanjut. Oleh sebab itu, penelitian mengenai kelimpahan dan keragaman artropoda tanah pada pertanaman jagung yang diberi perlakuan benih menggunakan fungisida perlu dilakukan.

Hasil penelitian ini akan bermanfaat untuk memberikan pertimbangan dalam pengelolaan penyakit bulai mengunakan fungisida melalui perlakuan benih agar memberi dampak negatif minimum terhadap biota yang terlibat dalam jaring-jaring makanan perombakan bahan organik di dalam tanah. 


\section{BAHAN DAN METODE}

Tempat dan Waktu Penelitian. Penelitian ini dilaksanakan di rumah plastik yang dibuat untuk pengujian pengendalian penyakit bulai di lahan petani Natar Lampung Selatan. Proses laboratorium dilakukan di Laboratorium Ilmu Hama Tumbuhan Fakultas Pertanian Universitas Lampung. Penelitian berlangsung dari bulan Januari sampai dengan Juni 2016.

Metode dan Pelaksanaan Penelitian. Rancangan percobaan yang digunakan adalah Rancangan Acak Kelompok (RAK) dan 3 kelompok berdasarkan arah mata angin. Terdapat 10 perlakuan yang terdiri dari 9 perlakuan fungisida yaitu HAB (Hydroxy Amino Benzimidazole), Ridomil (mefenoksan), Acrobat (dimetomorf), Target (fenamidone), Imax (mancozeb+cimonaxil), Fungisida-1, Fungisida-2, Fungisida-3, Fungisida-4 dan satu perlakuan lainnya yaitu Kontrol.

Media tanam yang digunakan yaitu tanah dan pupuk kandang dengan perbandingan 3:1 pada polibag $5 \mathrm{~kg}$. Tiap polibag ditanami 3 benih jagung, setelah tanaman jagung source bergejala penyakit bulai polybag ditanami dengan 4 benih jagung varietas NK 22. Sebelum ditanam, benih telah diberi perlakuan fungisida dengan dosis $5 \mathrm{~g} 1^{-1} \mathrm{~kg}$ benih.

Pengambilan sampel tanah dilakukan menggunakan ring sampel tanah dengan tinggi $5 \mathrm{~cm}$ dan diameter $5 \mathrm{~cm}$. Untuk tiap-tiap perlakuan diambil sampel tanah di sekitar perakaran. Pengambilan sampel tanah pertama dilakukan 5-7 hari sebelum tanam dan pengambilan sampel tanah kedua dilakukan saat jagung berumur $\pm 30-40$ hari setelah tanam.

Ekstraksi artropoda menggunakan alat Berlese Funnel Ekstraktor. Tanah yang telah diambil dari lahan, segera dibawa ke laboratorium untuk diekstraksi dengan proses inkubasi selama satu minggu. Menurut Anwar dan Ginting (2013), didasarkan atas sifat Collembola dan Acarina yang tidak suka cahaya (fototaksis negatif), maka artropoda yang terdapat pada ring sampel tanah dan disinari oleh lampu akan turun, jatuh dan masuk ke dalam tabung yang berisi ethylene glycol.

Berlese Funnel Ekstraktor terdiri atas corong beserta penyangga atau tempat dudukan corong, lampu/ bohlam berukuran 25 watt, saringan dan botol penampung yang berisi larutan ethylene glycol. Sampel tanah dalam ring sample dimasukkan ke dalam corong pada bagian bawah di pasang saringan dari kain strimin (screen) bermata lubang mesh $2 \mathrm{~mm}$ untuk menahan tanah dan di bagian atas ditutup dengan kain putih untuk menghindarkan masuknya fauna dari luar. Selanjutnya, permukaan contoh tanah disinari dan dipanasi dengan lampu bohlam. Pengaruh dari sinar dan panas tersebut akan menyebabkan artropoda seperti Collembola dan Acarina akan bergerak turun dari permukaan tanah, jatuh, dan masuk dalam botol penampung yang berisi larutan ethylene glycol.

Pengamatan dilakukan di laboratorium menggunakan mikroskop binokuler. Artropoda yang telah terkumpul dari hasil esktraksi lalu dipilah dan diamati di bawah mikroskop. Artropoda diidentifikasi sampai tingkat famili atau ordo menggunakan beberapa buku kunci determinasi Triplehorn dan Johnson (2005), Aoki (1982), Krantz dan Ainscough, (1990), Norton (1990), dan Philips (1990).Variabel yang diamati dalam penelitian ini adalah kelimpahan dan keragaman artropoda. Keragaman artropoda tanah diukur berdasarkan jumlah takson (ordo/ famili). Kelimpahan diartikan sebagai banyaknya individu dari suatu takson. Menurut Meyer (1996 dalam Widyastuti, 2006) Jumlah individu dapat dihitung dengan rumus sebagai berikut:

$$
\frac{\mathrm{IS}}{\mathrm{A}}=\mathrm{Lm}^{-2}
$$

IS = Rata-rata jumlah individu per sampel

$\mathrm{A}=$ Luas soil correr $\left(\mathrm{cm}^{2}\right)$ yaitu $ð \mathrm{r}^{2}=(2,5)^{2} \times 3,14$

yang nilainya dikonversi $\mathrm{ke}^{2}$

$\mathrm{I}=$ Jumlah individu $\mathrm{m}^{-2}$

Data kelimpahan dan keragaman artropoda dianalisis menggunakann analisis kovarians (ANKOVA) pada taraf nyata 5\% (Susilo dan Timotiwu, 2017). Nilai tengah dan SE data setiap variabel disajikan dalam bentuk grafik batang.

\section{HASIL DAN PEMBAHASAN}

Dari hasil pengamatan ditemukan artropoda yang masuk ke dalam kelas yaitu Insekta dan Arachnida. Kelas Insekta yang ditemukan terdiri dari 3 ordo dan 8 famili sedangkan Kelas Arachnida yang ditemukan terdiri dari 2 Ordo, 4 sub ordo dan 1 famili (Tabel 1). Berdasarkan kelompok fungsi, artropoda yang ditemukan meliputi artropoda pemakan jamur, artropoda pemakan alga, artropoda predator dan artropoda saprofag (Tabel 1). Artropoda pemakan jamur dan pemakan alga dapat disebut sebagai artropoda mikrofitik. Beberapa jenis famili atau sub ordo yang ditemukan pada pertanaman jagung yaitu Onychiuridae, Isotomidae, Hypogastruridae, Neelidae, Sminthuridae, Entomobryidae, Formicidae, Ptilidae, Pseudoscorpionida, Oribatida, Mesostigmata, Prostigmata, dan Astigmata. 
Analisis kovarians (ANKOVA) terhadap variabel kelimpahan seluruh artropoda, kelimpahan artropoda predator, kelimpahan artropoda saprofag, kelimpahan artropoda mikrofitik dan jumlah takson yang disajikan pada Tabel 2 menjelaskan bahwa nilai P regresi bersama variabel kelimpahan seluruh artropoda dan kelimpahan artropoda saprofag sangat nyata $(\mathrm{P}<0,01)$, untuk variabel kelimpahan artropoda predator nyata $(\mathrm{P}<0,05)$, tetapi untuk kelimpahan artropoda mikrofitik dan jumlah takson tidak nyata $(\mathrm{P}>0,05)$. Hal ini berarti kelimpahan seluruh artropoda, kelimpahan artropoda predator, kelimpahan artropoda saprofag setelah perlakuan fungisida dipengaruhi atau berkolerasi dengan kelimpahan seluruh artropoda, kelimpahan artropoda predator dan artropoda saprofag sebelum perlakuan, sedangkan untuk kelimpahan artropoda mikrofitik dan jumlah takson tidak berkorelasi.

Nilai $P$ hasil analisis kovarians pengaruh perlakuan terhadap kelimpahan seluruh artropoda, kelimpahan artropoda predator, artropoda saprofag, artropoda mikrofitik dan jumlah takson tidak nyata $(\mathrm{P}>0,05)$ (Tabel 2). Ini berarti perlakuan fungisida yang diaplikasikan pada benih jagung tidak mempengaruhi kelimpahan seluruh artropoda, artropoda predator, artropoda saprofag, artropoda mikrofitik dan jumlah takson.

Gambar 1 menyajikan kelimpahan seluruh artropoda sebelum dan sesudah aplikasi fungisida. Tinggi rendahnya kelimpahan seluruh artropoda setelah perlakuan fungisida, yang disajikan pada grafik batang tidak disebabkan oleh perlakuan namun dipengaruhi oleh

Tabel 1. Peringkat takson dan kelompok fungsi artropoda tanah yang ditemukan.

\begin{tabular}{cllll}
\hline No & Kelas & Ordo & Famili/Subordo & Kelompok Fungsi \\
\hline 1 & Insekta & Collembola & Onychiuridae & P. jamur (Mikrofitik) \\
2 & & Isotomidae & P. jamur (Mikrofitik) \\
3 & & Hypogastruridae & P. jamur (Mikrofitik) \\
4 & & Neelidae & P. jamur (Mikrofitik) \\
5 & & Sminthuridae & P. alga (Mikrofitik) \\
6 & & Entomobrydae & P. jamur (Mikrofitik) \\
7 & & Formichidae & Predator \\
8 & Coleoptera & Ptiliidae & Predator \\
9 & Arachnida & Pseudoscorpions & Pseudoscorpionida & Predator \\
10 & Acarina & Oribatida & Saprofag \\
11 & & Mesostigmata & Predator \\
12 & & Prostigmata & Predator \\
13 & & Astigmata & Saprofag \\
\hline
\end{tabular}

Tabel 2. Nilai P dari analisis kovarians pengaruh fungisida terhadap artropoda tanah.

\begin{tabular}{llll}
\hline Sumber & Regresi & Blok & Perlakuan \\
\hline Kel. seluruh artropoda & $0,003^{* *}$ & $0,593^{\text {tn }}$ & $0,308^{\text {tn }}$ \\
Kel. artropoda predator & $0,039^{*}$ & $0,380^{\text {tn }}$ & $0,155^{\text {tn }}$ \\
Kel. artropoda saprofag & $0,002^{* *}$ & $0,380^{\text {tn }}$ & $0,551^{\text {tn }}$ \\
Kel. artropoda mikrofitik & $0,455^{\text {tn }}$ & $0,098^{\text {tn }}$ & $0,285^{\text {tn }}$ \\
\hline Jumlah Takson & $0,224^{\text {tn }}$ & $0,208^{\text {tn }}$ & $0,406^{\text {tn }}$ \\
\hline
\end{tabular}

Keterangan: $\mathrm{tn}=$ tidak berbeda nyata pada taraf $5 \% ; *=$ berbeda nyata pada taraf $5 \%$ 
kelimpahan seluruh artropoda sebelum perlakuan. Kelimpahan seluruh artropoda sebelum perlakuan berkisar 6.285 - 22.930 individu $\mathrm{m}^{-2}$ dan setelah perlakuan berkisar 4.246 - 32.012 individu $\mathrm{m}^{-2}$. Gambar 2 menyajikan grafik garis regresi hubungan kelimpahan seluruh artropoda sebelum dan sesudah perlakuan beberapa jenis fungisida. Regresi menunjukkan bahwa peningkatan kelimpahan seluruh artropoda sebelum perlakuan diikuti oleh peningkatan kelimpahan artropoda sesudah perlakuan pada semua perlakuan fungisida. Hal ini menunjukkan bahwa peningkatan atau penurunan kelimpahan seluruh artropoda sesudah perlakuan ditentukan oleh kelimpahan seluruh artropoda sebelum perlakuan.

Pada Gambar 3 disajikan kelimpahan artropoda predator sebelum dan sesudah perlakuan fungisida dalam bentuk grafik batang. Kelimpahan artropoda predator sebelum perlakuan berkisar 2.718 - 8493 individu $\mathrm{m}^{-2}$ dan sesudah perlakuan berkisar 1.868 - 12.739 individu $\mathrm{m}^{-2}$. Pada Tabel 2 ditunjukkan bahwa nilai P regresi bersama pada kelimpahan artropoda predator tersebut nyata, yang berarti kelimpahan seluruh artropoda sesudah perlakuan dipengaruhi oleh kelimpahan seluruh artropoda sebelum perlakuan. Gambar 4 menyajikan grafik regresi hubungan kelimpahan artropoda predator sebelum dan sesudah perlakuan. Pada tiap perlakuan menunjukkan bahwa peningkatan atau penurunan kelimpahan sebelum perlakuan diikuti pula oleh peningkatan atau penurunan kelimpahan sesudah perlakuan. Hal ini menunjukkan bahwa peningkatan atau penurunan kelimpahan seluruh artropoda sebelum perlakuan diikuti kelimpahan seluruh artropoda sesudah perlakuan.

Pada Gambar 5 disajikan kelimpahan artropoda saprofag sebelum dan sesudah perlakuan fungisida dalam

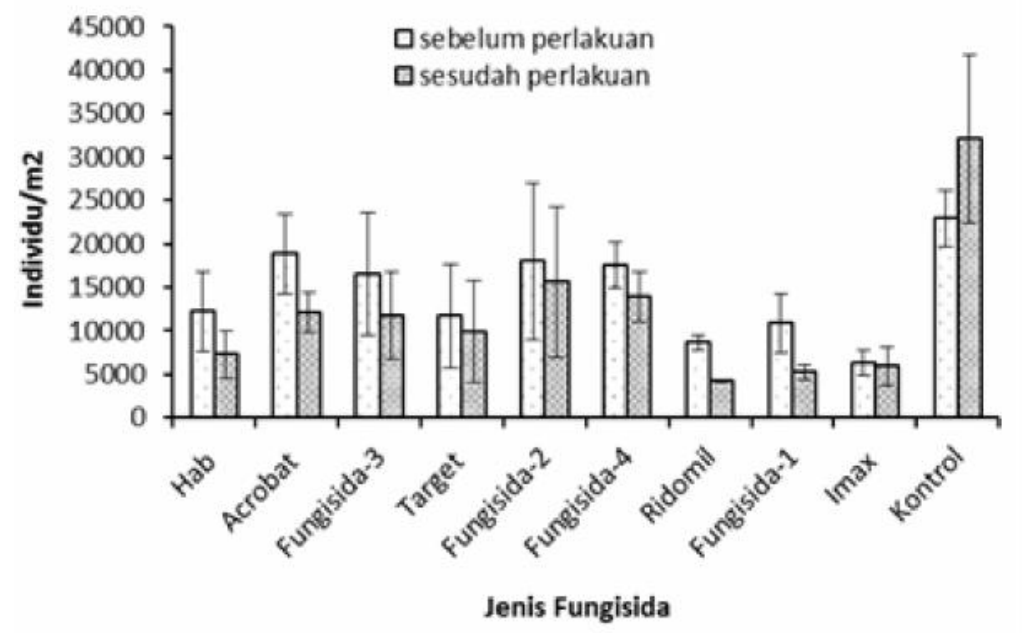

Gambar 1. Grafik kelimpahan seluruh artropoda (mean \pm SE) sebelum dan sesudah perlakuan beberapa jenis fungisida

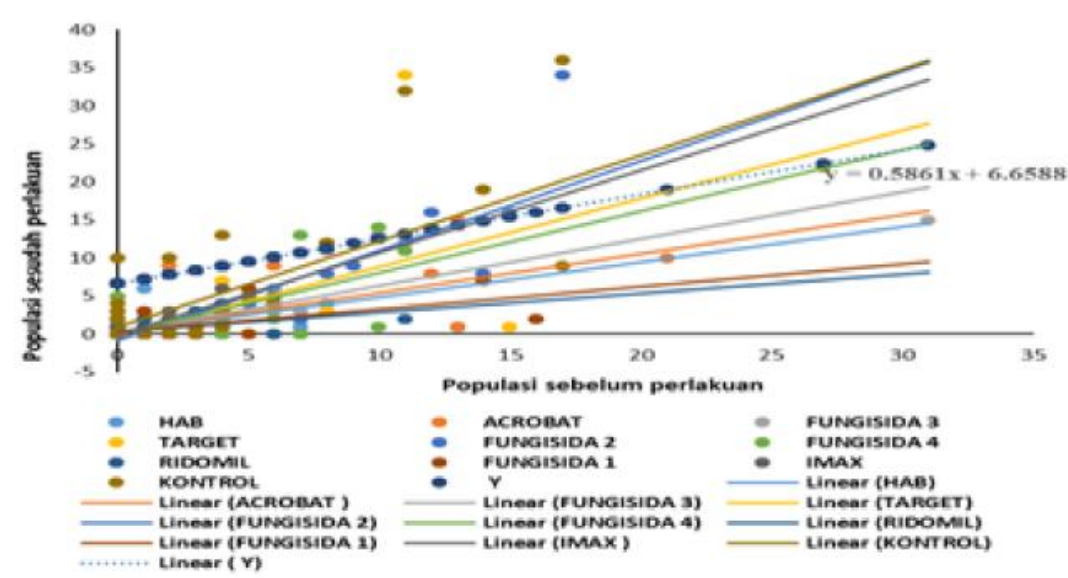

Gambar 2. Regresi hubungan kelimpahan seluruh artropoda sebelum dan sesudah perlakuan beberapa jenis fungisida 


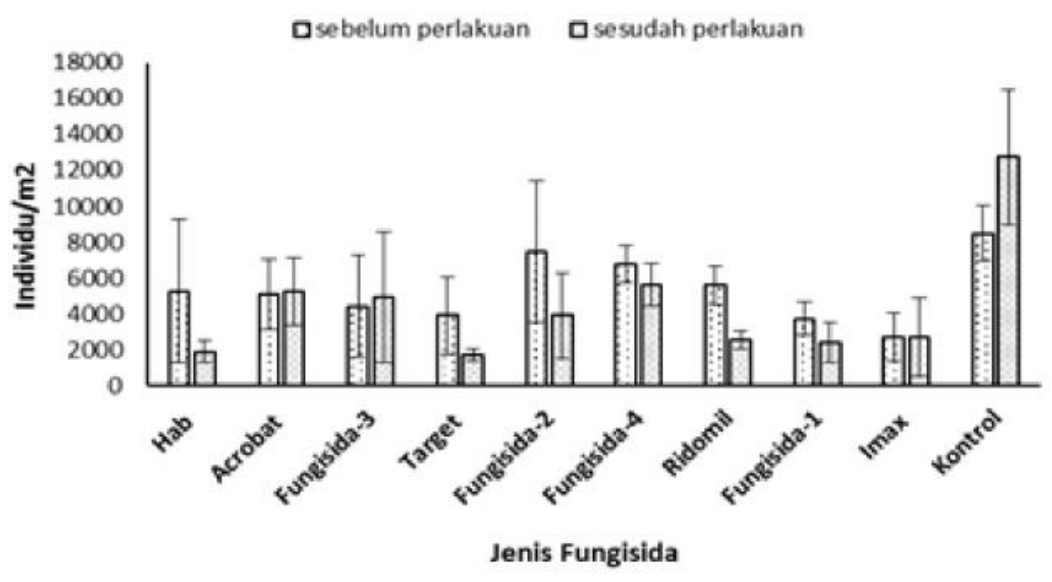

Gambar 3. Grafik kelimpahan artropoda (mean \pm SE) kelompok makan predator sebelum dan sesudah perlakuan fungisida.

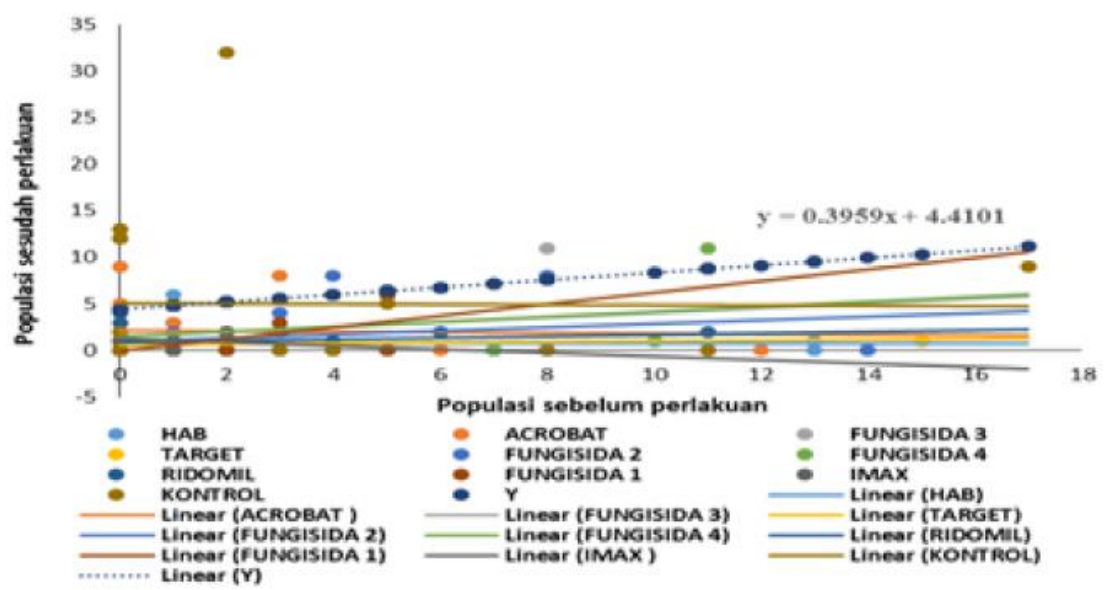

Gambar 4. Regresi hubungan kelimpahan artropoda predator sebelum dan sesudah perlakuan beberapa jenis fungisida.

bentuk grafik batang. Kelimpahan artropoda saprofag sebelum perlakuan berkisar 1.529 - 11.210 individu $\mathrm{m}^{-2}$ dan sesudah perlakuan berkisar 1.358 - 13.927 individu $\mathrm{m}^{-2}$.

Sama halnya dengan kelimpahan seluruh artropoda, nilai P regresi kelimpahan artropoda saprofag yang ditampilkan pada Tabel 2 menunjukkan sangat nyata. Gambar 6 menyajikan grafik garis regresi hubungan kelimpahan artropoda saprofag sebelum dan sesudah perlakuan beberapa jenis fungisida. Regresi menunjukkan bahwa peningkatan sumbu x yaitu kelimpahan artropoda saprofag sebelum perlakuan diikuti oleh peningkatan sumbu y yaitu kelimpahan artropoda saprofag sesudah perlakuan pada semua perlakuan fungisida. Hal ini menunjukkan bahwa peningkatan atau penurunan kelimpahan artropoda saprofag sesudah perlakuan ditentukan oleh kelimpahan artropoda saprofag sebelum perlakuan.
Keragaman artropoda tanah diukur dari jumlah takson yang ditemukan. Tinggi rendahnya jumlah takson yang bervariasi pada grafik tidak dipengaruhi oleh perlakuan dan jumlah takson sebelum perlakuan. Ratarata jumlah takson artropoda sebelum perlakuan berkisar 4,7 - 7,0 dan sesudah perlakuan berkisar 3,7 - 6,3.

Hasil penelitian ini menunjukkan bahwa perlakuan benih menggunakan fungisida tidak mempengaruhi kelimpahan dan keragaman artropoda tanah. Hasil penelitian ini sejalan dengan temuan Rapoport dan Sanchez (1968 dalam Edwards dan Thompson, 1972) yang menyatakan bahwa perlakuan fungisida tidak menyebabkan perubahan yang signifikan terhadap populasi tungau dan Collembola dalam tanah. Fungisida yang diaplikasikan ke dalam tanah tidak memberikan efek yang menyebabkan penurunan populasi Collembola. Adamski, dkk. (2009) juga menyatakan bahwa fungisida Mancozeb tidak mempengaruhi kelimpahan fauna tanah. 


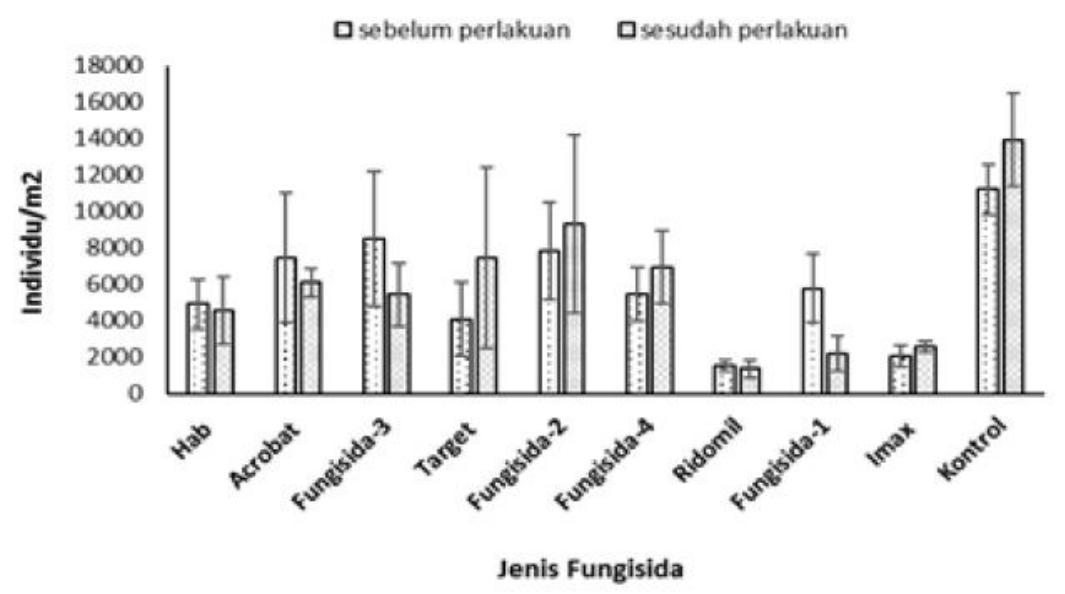

Gambar 5. Grafik kelimpahan artropoda saprofag (mean \pm SE) sebelum dan sesudah perlakuan fungisida.

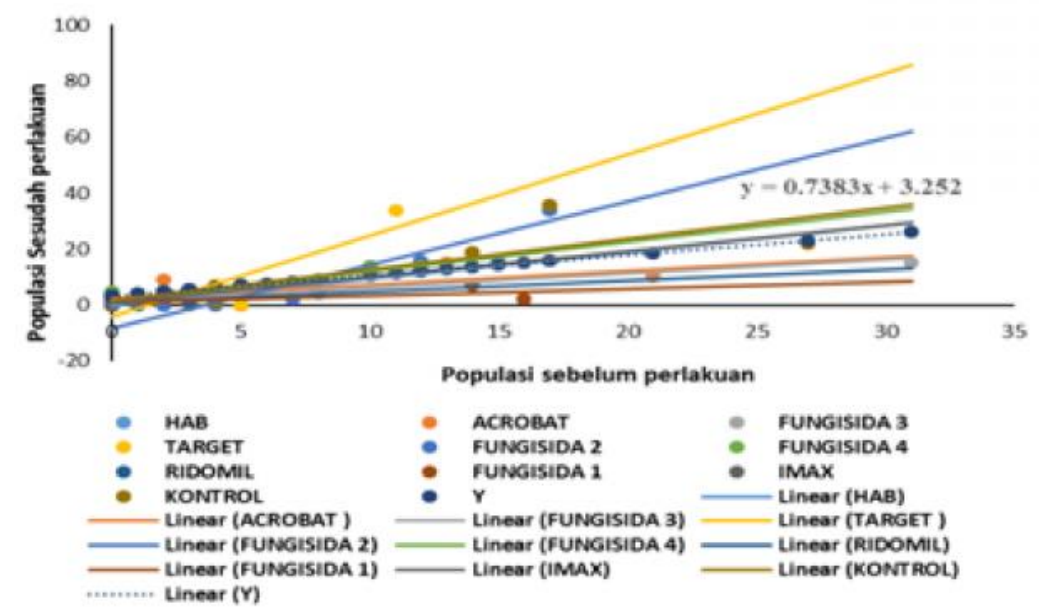

Gambar 6. Regresi hubungan kelimpahan artropoda saprofag sebelum dan sesudah perlakuan beberapa jenis fungisida.

Namun sebaliknyan laporan Van-Zwieten, dkk. (2004) menyatakan bahwa aplikasi fungisida berbahan aktif tembaga dapat meninggalkan residu yang berdampak buruk terhadap aktivitas mikrobia dan artropoda non-target seperti tungau, terutama penghuni lapisan atas tanah. Walia, dkk. (2014) juga menyatakan bahwa, pestisida yang diaplikasikan untuk mengendalikan jamur patogen tumbuhan selalu akan mempengaruhi kelimpahan dan kinerja organisme lainnya.

Dari hasil penelitian ini dapat diketahui bahwa penggunaan fungisida yang diaplikasikan sebagai perlakuan benih atau seed treatment tidak mengganggu aktivitas artropoda dalam tanah. Penggunaan fungisida pada perlakuan benih tidak menyebabkan terganggunya aktivitas artropoda pada tanah, Fungisida yang dibalurkan pada benih jagung dengan tujuan untuk melindungi benih jagung dari jamur patogen tanaman cukup aman karena tidak memberikan dampak negatif terhadap artropoda dalam tanah. Namun demikian penggunaan fungisida yang termasuk bahan beracun harus tetap dilakukan dengan bijaksana. Untuk mengurangi resiko resistensi jamur patogen dan menjaga ekosistem agar tetap seimbang.

\section{KESIMPULAN}

Berdasarkan hasil penelitian yang telah dilakukan dapat ditarik kesimpulan bahwa pada pertanaman jagung ditemukan 9 famili dan 4 sub ordo artropoda yang terdiri dari 3 kelompok makan yaitu predator, saprofag dan mikrofitik yang meliputi pemakan jamur dan pemakan alga. Perlakuan benih tanaman jagung menggunakan fungisida tidak mempengaruhi kelimpahan dan keragaman artropoda di dalam tanah. 


\section{SANWACANA}

Penelitian ini mendapatkan fasilitas Tim Penelitian pengujian fungisida perlakuan beih untuk pengendalian penyakit bulai. Dalam kesempatan ini diucapkan terima kasih kepada Tim Penelitian Jurusan Proteksi Tanaman

\section{DAFTAR PUSTAKA}

Adamski Z., J. B ${ }^{3}$ oszyk, K. Piosik dan K. Tomczak. 2009. Effects of diûubenzuron and mancozeb on soil microarthropods: a long-term study. Biological Lett. 46(1): 3-13.

Andriani, L.F., R. Rahadian dan M. Hadi. 2012. Pengaruh biostarter pengurai bahan organik terhadap kapasitas infiltrasi air dan struktur komunitas mesofauna tanah. Jurnal Sains dan Matematika. 20(1): 11-15.

Anwar E.K dan R.C.B Ginting. 2013. Mengenal Fauna Tanah dan Cara identifikasinya. Badan Penelitian dan Pengembangan Pertanian. IAARD Press. Jakarta.

Aoki, J. 1982. New species of oribatid mites from the Southern Island of Japan. Bulletin Institute of Environmental Science and Technology, Yokohama National University 8:173-188.

Edwards, C.A. dan A. R. Thompson.1973. Pesticides and the soil fauna. In: Gunther, F.A and J.D. Ghunter (Editor). Residue Review: Residues of Pesticides and Other Contamination in the Total Environment. Springer Verlag. Berlin 780.

Kranzt, G.W dan B.D Ainscough. 1990. Acarina: Mesostigmata (Gamasida). In: D.L Dindal (Ed), Soil Biology Guide. John Willey and Sons. New York. pp: 583-666.
Norton R.A. 1990. Acarina: Oribatida. In D.L Dindal (Ed). Soil Biology Guide. John Willey and Sons. New York. pp: 779-804.

Philips J.R. 1990. Acarina: Astigmata (Acaridida). In D.L Dindal (Ed). Soil Biology Guide. pp: 757778 .

Semangun, H. 1993. Penyakit-Penyakit Tanaman Pangan di Indonesia. Gadjah Mada University Press.Yogyakarta

Susilo, F.X dan P.B. Timotiwu. 2017. Penggunaan Regresi untuk Analisis Data Riset Pertanian dan Biologi. Aura. Bandar Lampung.

Triplehorn C.A and N.F. Johnson. 2005. Borror and DeLong's Introduction to the Study of Insects. Thompson Brooks. United States of America. 186 hlm.

Van-Zwieten, L., G, Merrington"and M., dan VanZwieten. 2004. Review of impacts on soil biota caused by copper residues from fungicide application. Wollongbar Agricultural Institute. Australia. Available online at http:// www.regional.org.au.

Walia, A., P. Mehta., S. Guleria, A. Chauhan, dan C. K. Shirkot. 2014. Impact of Fungicide Mancozeb at Different Application Rates on Soil Microbial Populations, Soil Biological Processes, and Enzyme Activities in Soil. Scientific World Journal. Publish online. doi: 10.1155/2014/ 702909.

Widyastuti, R. 2006. Feeding rate of soil animals in different ecosystems in Pati, Indonesia. Journal of Biosciences 13(3): 119-123. 